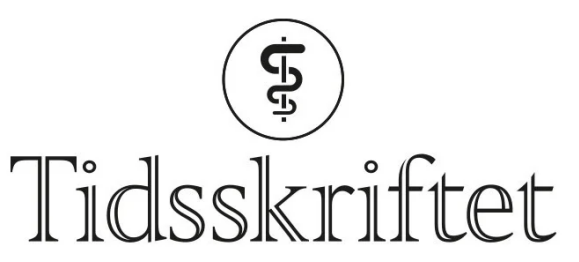

DEN NORSKE LEGEFORENING

\title{
Hjelp til øyeblikkelig hjelp-psykiatri
}

ANMELDELSER

\section{TORFINN HYNNEKLEIV}

Overlege, Avdeling for akuttpsykiatri og psykosebehandling Reinsvoll, Sykehuset Innlandet

\section{Akutt-}

\section{psykiatrisk}

\section{håndbok}

F Groenoal

Tore Tveitstul, Siv Elin Pignatiello

Akuttpsykiatrisk håndbok

455 s, tab, ill. Oslo: Gyldendal, 2020. Pris NOK 549

ISBN 978-82-05-512498

Håndbokas mål er å gjennomgå akuttpsykiatriske tilstander og tiltak som er særlig aktuelle de første tre døgn. Teksten er femdelt: Akuttpsykiatrisk vurdering;

Sykdommer/behandling; Rusrelaterte tilstander/behandling; Psykofarmakologi; Lovverk.

Boka har tiltalende layout og pedagogiske figurer. Forordet minner forbilledlig om at akutt psykisk sykdom innebærer fortvilelse og forlegenhet. Dette kunne vært fulgt opp med en framstilling av eksistensielle og etiske dimensjoner i akuttpsykiatrien.

Forfatterne beskriver kliniske innkomstundersøkelser, men uten å beskrive relevante akuttnevrologiske undersøkelser. Det mangler også en systematisk omtale av epilepsiutløste psykiatriske tilstander og psykogene ikke-epileptiske anfall (PNES). Boka 
ville tjent på å omtale faglige utfordringer og logistikkproblemer ved behov for raske overføringer til andre avdelinger eller kommunen. Innholdet i epikrisene, ikke minst med påpekning av viktigheten av en solid sluttvurdering, kunne gjerne vært omtalt.

De psykiatriske sykdomsgruppene blir presentert samlet (unntatt angst, av en eller annen grunn). Ikke-akutte eller teoretiske avsnitt, som «Hvorfor liker vi rusmidler?» kunne ha vært erstattet med mer praksisnært innhold, slik som gatebetegnelser på rusmidler. Farmakologiske tiltak beskrives oversiktlig, også som tabellariske oppsummeringer og algoritmer. Seponerings- og etterlevelsesproblematikk ville vært nyttig å ha tematisert.

Generelle litteraturhenvisninger kunne vært beskåret og erstattet med nasjonale nettsteder om tvangs(reduksjons)tiltak (tvangsforskning.no) og rus (lommerus.no). En fagguide i farta trenger et godt stikkordregister. Bokinnholdet viste seg heldigvis mer omfattende enn resultatet av undertegnedes stikkordtest. En appversjon med god søkefunksjon ville ha vært tjenlig.

Akuttpsykiatrien er i begrenset grad basert på evidens, og særlig bør de kustodiale dimensjoner problematiseres transparent. Forfatterne formidler at manibehandling må igangsettes raskt ved bl.a. medikamenter. Men det kan oppstå situasjoner der pasienten har loven og statsforvalteren på sin side, slik at medisineringen ikke starter raskt. Dilemmaer som dette kunne vært diskutert, gjerne med innledende vignetter. Kontrollkommisjonens roller mangler omtale. Et ønske fra novisen vil nok være formuleringstips ved paragrafvurderinger og vedtak.

Boka blir presentert som hjelpemiddel for klinikere som møter akutt og alvorlig psykisk syke. Samlet sett er det grunnlag for å støtte den påstanden. Vår avdeling har distribuert den til behandlerne - og første vaktlege er observert gående med boka i hånda. Da har forfatterne lykkes med å skrive en genuin håndbok.

Publisert:3. mai 2021. Tidsskr Nor Legeforen. DOI: 10.4045/tidsskr.21.0144

(C) Tidsskrift for Den norske legeforening 2023. Lastet ned fra tidsskriftet.no 26. april 2023. 